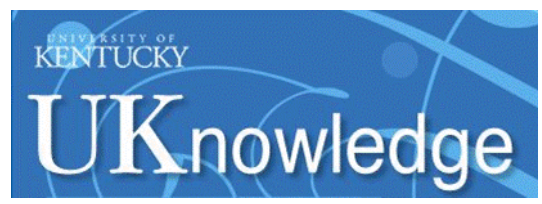

Kentucky Journal of Equine, Agriculture, \& Natural Resources Law

\title{
Plugging Problems: How States in the Ohio River Basin can Address Orphan Oil and Gas Wells
}

Connor Hicks

University of Kentucky

Follow this and additional works at: https://uknowledge.uky.edu/kjeanrl

Part of the Natural Resources Law Commons, Oil, Gas, and Mineral Law Commons, and the Water Law Commons

Right click to open a feedback form in a new tab to let us know how this document benefits you.

\section{Recommended Citation}

Hicks, Connor (2020) "Plugging Problems: How States in the Ohio River Basin can Address Orphan Oil and Gas Wells," Kentucky Journal of Equine, Agriculture, \& Natural Resources Law: Vol. 12: Iss. 3, Article 4. Available at: https://uknowledge.uky.edu/kjeanrl/vol12/iss3/4

This Note is brought to you for free and open access by the Law Journals at UKnowledge. It has been accepted for inclusion in Kentucky Journal of Equine, Agriculture, \& Natural Resources Law by an authorized editor of UKnowledge. For more information, please contact UKnowledge@lsv.uky.edu. 


\title{
Plugging Problems: How States in the Ohio River Basin Can Address Orphan Oil and Gas Wells
}

\author{
Connor D. Hicks*
}

\section{INTRODUCTION}

The Ohio River ("Ohio") is the aqueous heart of a large portion of the country. ${ }^{1}$ The Ohio River begins in Pittsburgh, Pennsylvania, and flows 981 miles to Illinois before finding its way to the Mississippi. ${ }^{2}$ The Ohio navigates through six states, but the Basin reaches much farther. ${ }^{3}$ Indiana, Kentucky, Ohio, and West Virginia sit within the Ohio River Basin, which also extends into parts of seven other states. ${ }^{4}$ As a primary tributary to the Mississippi River, any pollutants arriving in Ohio will consequently find its way to the Mississippi and its watershed. ${ }^{5}$

Abandoned oil and gas wells are a major cause of pollutants in the Ohio River. ${ }^{6}$ Oil and gas drilling in the region predates $1860 .{ }^{7}$ Due to fluctuating oil prices and increased

* Notes Editor, KY. J. EQUine, AGRIC., \& NAT. ResourCes L., 2020-2021;

B.S.J. 2018, West Virginia University; J.D. expected May 2021, University of Kentucky J. David Rosenberg College of Law. The author would like to thank his parents, David and Sue Hicks, for endless support, and Professor Zachary A. Bray for invaluable assistance and guidance in development of this piece.

1 See The Ohio River Valley Water Sanitation Comm'N, The Nat'L Park

Serv., Rivers, Trails, \& Conservation Assistance Program \& The OHio River Basin COMM'N, "What's A RIVER WORTh?" A VALUATION SURVEY OF THE OHIO RIVER CORRIDOR 2-6 (1994).

2 Ohio River Facts, OHIO RIVER Found.,

https://www.ohioriverfdn.org/education/ohio_river_facts/ [https://perma.cc/BY4V-HGFL] (last viewed Oct. 26, 2019).

${ }^{3}$ See Ohio River Basin, OHIo RIVER Basin Consortium for Res. \& Educ., https://www.ohio.edu/orbcre/basin/index.html [https://perma.cc/6ZRL-M8A7] (last viewed Oct. 21, 2019).

${ }^{4}$ See id. (showing that portions of Illinois, Maryland, New York, North Carolina, Pennsylvania, Tennessee, and Virginia also sit within the basin. Due to the small size of the industry in certain states, limited data is available for abandonment in Maryland, North Carolina, Tennessee, and Virginia. Reader should assume that these states are not included in reference to the "Basin" unless explicitly stated).

${ }^{5}$ Benjamin Elisha Sawe, Major Tributaries of the Mississippi River, NEw

WORLD ATLAS (Oct. 12, 2019), https://www.worldatlas.com/articles/major-tributaries-ofthe-mississippi-river.html [https://perma.cc/67N9-5WA3].

${ }^{6}$ See E. Allison \& B. Mandler, Abandoned Wells: What Happens to Oil and

Gas Wells When They Are No Longer Productive, AM. Geosciences Inst. (June 1, 2018), https://www.americangeosciences.org/sites/default/files/AGI_PE_AbandonedWells_web_fin al.pdf [https://perma.cc/C6FX-3KQ2].

${ }_{7}$ Abandoned and Orphan Oil and Gas Wells and the Well Plugging Program, PA. DeP’T ENVTL. PROT. 
competition, companies continually go out of business and leave tens of thousands of wells abandoned, or "orphaned."8 United States (U.S.) oil production reached an all-time high of 12.4 million barrels per day in 2019 due, in part, to reductions in industry regulations under the Trump administration. ${ }^{9}$ With new wells drilled each month, it is important for states that comprise the watershed of the Ohio River to ensure proper precautions to keep the number of orphaned wells low in the future. ${ }^{10}$

Orphaned wells are abundant in Basin states, but often go unnoticed. Over three million people receive drinking water from the Ohio River and its watershed.11 Cumulatively, nearly ten percent of the U.S. population resides somewhere in the Basin. ${ }^{12}$ Although the overabundance of abandoned wells may seem unimportant to the nescient resident, statistics are telling. ${ }^{13} \mathrm{In}$ Kentucky, where fifty-two of 102 counties have produced petroleum, ${ }^{14}$ there are fourteen-thousand abandoned oil and gas wells. ${ }^{15}$ Pennsylvania also houses thousands of orphaned wells. The Pennsylvania Department of Environmental Protection (DEP) estimates anywhere from 100 thousand and 560 thousand abandoned wells in the Keystone State. ${ }^{16}$

https://www.dep.pa.gov/Business/Energy/OilandGasPrograms/OilandGasMgmt/Document s/8000-FSDEP1670.pdf [https://perma.cc/2PBA-2AE2] (last viewed Oct. 1, 2019)

(for the purposes of this Note, "abandoned" and "orphaned" will be used interchangeably).

8 Id.

${ }^{9}$ Liz Hampton, U.S. Oil and Gas Regulatory Rollbacks Under Trump, REUTERS

(Aug. 29, 2019), https://www.reuters.com/article/us-usa-climate-

regulationsfactbox/factbox-u-s-oil-and-gas-regulatory-rollbacks-under-trumpidUSKCN1VJ2BP [https://perma.cc/KVZ9-FS45].

10 See New Wells Drilled to the Moon and Back by 2023, RYstad EnERGY

(Apr. 29, 2019), https://www.rystadenergy.com/newsevents/news/press-releases/Newwells-drilled-to-the-moon-and-back-by-2023/ [https://perma.cc/PU86-MDH4].

11 OHIO RIVER VALLEY WATER SANITATION COMM'N ET AL, supra note 2.

${ }^{12} I d$.

13 See PA. DeP'T EnVtl. Prot., supra note 7.

${ }_{14}$ Kentucky's Great American Oil Well, AM. OIL \& GAS HIST. Soc'Y, https://aoghs.org/petroleum-pioneers/kentuckys-great-american-well/ [https://perma.cc/N8Q8-TYFV] (last viewed Apr. 22, 2020).

15 Ryan Van Velzer, Kentucky Moves Closer to Capping 14,000 'Orphaned' Oil

Wells, WFPL NEWS (Feb. 19, 2019), https://wfpl.org/kentucky-moves-closer-to-capping14000-orphaned-oil-wells/ [https://perma.cc/VJ9Q-CC5Q]; Kentucky's Great American Oil Well, supra note 14.

${ }^{16}$ Isabelle Weber, Abandoned Wells in Pennsylvania: We're Not Doing Enough, FRACTRACKER ALLIANCE (Aug. 8, 2019), https://www.fractracker.org/2019/08/paabandoned-wells/ [https://perma.cc/97R8-QKPB ]; State Symbols, PENNSYLVANIA, https://www.pa.gov/guides/state-symbols/ [https://perma.cc/ZGA2-DYLB] (last viewed Apr. $22,2020)$. 
Orphaned wells also pose legitimate health and safety risks. Orphaned wells have the potential to contaminate drinking water, leak methane and other toxins into the atmosphere, and spread dangerous pollutants to surrounding areas when left unsealed and unmonitored. ${ }^{17}$ Thus, it is important that states locate, document, and plug orphaned wells within state borders. The process is complicated because locating abandoned wells (many on private property) poses difficulties and requires the costly process of sealing the wells. ${ }^{18}$

Issues arise because states have various regulations and classifications of abandoned wells. ${ }^{19}$ States have different quantitative and qualitative guidelines, which frustrates coordination efforts among their neighboring states. $^{20}$ Pennsylvania has the highest number of regulations of oil and gas wells while also having one of the least-stringent regulation systems in the country. ${ }^{21}$ Kentucky falls near the bottom of the nation in both the quantity and the quality of its restrictions. ${ }^{22}$ The rest of the Basin states differ significantly in quantitative regulations and correlated stringency, making a coordinated effort necessary. ${ }^{23}$ Common ground that adequately holds owneroperators accountable, while remaining economically feasible, must be established.

This Note addresses how states located within the Basin can address and repair the problem of abandoned oil and gas wells within their state borders. It also addresses the current drilling regulations and how they can be fixed to prevent further abandonment. Further, this Note will explain how states can mitigate the effects of abandoned wells in a cost-effective,

\footnotetext{
${ }^{17}$ Allison \& Mandler, supra note 6.

18 Jim Malewitz, Abandoned Texas Oil Wells Seen As "Ticking Time Bombs" of Contamination, TEX. TRIBUNE (Dec. 21, 2016),

https://www.texastribune.org/2016/12/21/texas-abandoned-oil-wells-seen-ticking-timebombs-/ [https://perma.cc/8355-WEXN] (explaining conclusions by the Texas Railroad Commission over a five-year period which found the average cost of plugging a well to be $\$ 20,100)$.

19 Jacqueline Ho, Alan Krupnick, Katrina McLaughlin, Clayton Munnings \& Jhih-Shyang Shih, Plugging in the Gaps in Inactive Well Policy, RES. FOR FuTURE 4 (May 2016), https://media.rff.org/documents/RFF-Rpt-PluggingInactiveWells.pdf [https://perma.cc/9Y22-C8HQ].

${ }_{20} I d$. at $18-19$.

${ }^{21}$ See id. at 20.

22 See id.

${ }^{23}$ See id.
} 
efficient manner while still permitting sustainable growth and production in this lucrative industry.

Part I lays out the historical background of oil and gas well drilling and production in the United States. Particularly, it addresses the Basin, the exponential growth of drilling nationally since 1859, and the lack of regulations that led to the current difficulties of locating and plugging abandoned wells. ${ }^{24}$ It also examines the harmful economic, environmental, public health, and safety risks created by orphan wells in the Ohio Basin region. Part II addresses the rising issue of abandoned wells not only in the Basin, but across the country. Further, this section gives an overview of the causes for well abandonment, as well as an analysis of the current bond system inadequacies in the region. Part II also considers the current "oil boom" and possible adverse effects the Trump administration's regulation cuts might have on handling of well abandonment and the resulting environmental harm. ${ }^{25}$ Part III discusses recommendations for the Ohio River Basin states. It proposes measures that have produced positive results around the country and in the Basin, and advocates for the adoption of these measures in regions surrounding the Ohio River and its tributaries to create similar results. Part III's recommendations include plugging existing abandoned wells and implementing new industry regulations to prevent new wells from falling into abandoned status. Further, this Part discusses the political, economic, and technical roadblocks in implementing these measures. The widespread problem of abandoned oil and gas wells could be adequately mitigated if Basin states move quickly with proactive measures. A strong first step is a complete overhaul of the current bond system across the Basin, but substantive change will require much more.

\footnotetext{
${ }^{24}$ Weber, supra note 16.

${ }_{25}$ Matt Egan, America's Oil Boom Will Break More Records This Year. OPEC is Stuck in Retreat, CNN Bus. (June 14, 2019), https://www.cnn.com/2019/06/10/business/oilboom-production-opec/index.html [https://perma.cc/CPN4-ZAWX].
} 


\section{THE HISTORY OF THE OIL AND GAS INDUSTRY IN THE OHIO RIVER BASIN}

\section{A. History of Oil and Gas Wells in the Ohio River Basin}

The history of drilling in the Ohio River Basin is as rich as the oil and gas produced in the region. Edwin Drake drilled the first oil well in the U.S. on August 27, 1859 in Titusville, Pennsylvania. ${ }^{26}$ The first barrel of oil was delivered to a Pittsburgh refinery at twenty dollars per barrel and later sold as lamp fuel for forty dollars per barrel. ${ }^{27}$ However, oil gathering in the Basin predates this first delivery by almost fifty years. ${ }^{28}$ Prior to Drake's well, drillers in Burkesville, Kentucky discovered oil by accident while searching for brine using a spring-pole device..$^{29}$ Even earlier, oil was extracted in Noble County, Ohio, in $1814 . .^{30}$ While present-day production in the Ohio River Basin is largely insignificant compared to many western states, the region remains the birthplace of the American oil industry; it predates the industry's realization of massive oil reserves present in Alaska, Texas, and other western states. ${ }^{31}$

Continuing its rich history, well production is still prevalent within the Ohio River Basin. As of 2015, nearly onequarter of the nation's 1.7 million registered wells sat in one of the states classified as being within the Basin. ${ }^{32}$ However, Basin well production is negligible when compared to certain western states. ${ }^{33}$ What is more concerning, however, is the overwhelming percentage of abandoned wells in the Basin juxtaposed to its

${ }_{26}$ First American Oil Well, AM. OIL \& Gas Hist. SoC’y (June 20, 2019),

https://aoghs.org/petroleum-pioneers/american-oil-history/ [https://perma.cc/X7AP-ZDTZ].

27 Id.

28 AM. OIL \& GAS HiST. SOC’Y, supra note 15.

${ }^{29} I d$.

${ }^{30} I d$.

${ }^{31}$ Ho et al., supra note 19, at 53 (noting the entirety of the Ohio River Basin states produce one percent of the nation's crude oil, while Alaska, California, and Texas are responsible for two-thirds of the country's production).

32 Matt Kelso, 1.7 Million Wells in the U.S. - A 2015 Update, Fractracker ALLIANCE (Aug. 3, 2015), https://www.fractracker.org/2015/08/1-7-million-wells/ [https://perma.cc/Q72E-MRYR].

33 See Crude Oil Production, U.S. Energy InFo. Admin. (Feb. 28, 2020), https://www.eia.gov/dnav/pet/pet_crd_crpdn_adc_mbblpd_a.htm [https://perma.cc/TN68SQHU]. 
minute amount of production. ${ }^{34}$ For example, Kentucky produced 142,549 barrels of crude oil from 1981 to $2014 .{ }^{35}$ This accounts for 0.2 percent of America's total output during that time. ${ }^{36}$ However, in 2006, there were 10,600 abandoned wells in the Bluegrass State. ${ }^{37}$ Despite limited production, Kentucky is responsible for nearly eighteen percent of the nation's abandoned wells on a waitlist for plugging. ${ }^{38}$ Other than Texas, which has the largest number of abandoned wells, the Basin is responsible for three of the next four highest percentages of the country's abandoned well population awaiting plugging. ${ }^{39}$

Ultimately, the Basin's current abandonment issues are attributable to the history and timing of drilling in the region compared to the rest of the country. Wyoming, for example, is responsible for more crude oil and natural gas production than the entire Basin. ${ }^{40}$ At the time Drake's well in Pennsylvania became the first in the country, ${ }^{41}$ the Wyoming Territory was still ten years from being organized and thirty-one years from statehood. ${ }^{42}$ Thus, while the development of the oil industry was delayed in the west, it flourished in the Basin.

Indiana's "gas boom" began in the 1890s when a large portion of the state's seventy-thousand wells were built. ${ }^{43}$ The location of the majority of these wells were in east central Indiana, near the Ohio River. ${ }^{44}$ Because the state did not have modern standards for abandoned wells until 1947, many wells were abandoned without any regulations requiring reporting or closure. $^{45}$ Only 5,000 of the 70,000 wells in Indiana are still

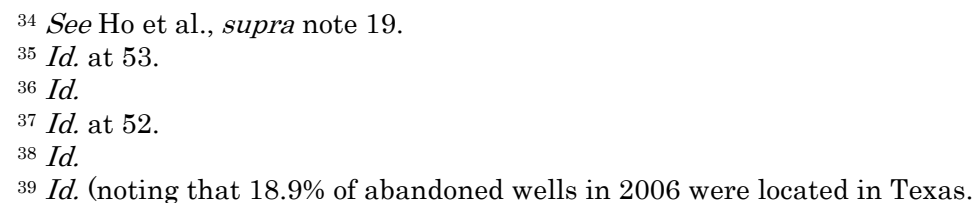
Kentucky, Pennsylvania, Kansas, and New York are the next highest percentage-wise).

${ }^{40}$ Ho et al., supra note 19 , at 53-54.

${ }^{41}$ Drake Oil Well, ASME, https://www.asme.org/about-asme/engineeringhistory/landmarks/40-drake-oil-well [https://perma.cc/6GPQ-N6B4] (last viewed Mar. 3, 2020).

${ }^{42}$ Wyoming History, STATE WYo., $\quad$ www.wyo.gov/about-wyoming/wyominghistory [https://perma.cc/LA3G-ZKKM] (last viewed Oct. 17, 2019).

43 Orphaned \& Abandoned Well Program, IND. DeP’T NAT. RES., https://www.in.gov/dnr/dnroil/files/abandoned.pdf [https://perma.cc/V485-48E8] (last viewed Oct. 19, 2019).

${ }^{44} \mathrm{Id}$.

${ }^{45} I d$. 
operating today, leaving a large number of wells that were drilled during the boom now abandoned and posing potential risks. ${ }^{46}$ The other states in the Basin face issues similar to Indiana, where the flux of oil and gas drilling came and went before states could establish standards for regulation. ${ }^{47}$

As the industry developed, so did modern standards of well construction. ${ }^{48}$ These standards granted western states, where development was delayed, an inherently more regulated system of wells than states with wells predating modern regulations. Many wells built before 1930 were not obligated to contain multiple cement barriers, which is a modern requirement to prevent migration into water sources. ${ }^{49}$ While Pennsylvania, Kentucky, Ohio, and the rest of the Basin are not seen as major oil and gas producers today, there is a significant number of abandoned wells in the region compared to the rest of the nation, likely because the industry began alongside the Ohio River. ${ }^{50}$

\section{B. Dangers of Abandoned Wells}

\section{Financial Risks}

The abundance of abandoned oil and gas wells in the Ohio River Basin pose a variety of risks, the most concerning of which may be the financial cost of mitigating the effects of the wells and future costs of correcting the issue if not adequately dealt with in the present.

Many orphaned wells sit on private property, and while landowners are generally not liable for the effects of wells left on their property by the owners, they could be held responsible in certain situations. ${ }^{51}$ In Pennsylvania, courts have interpreted the text of the Clean Streams Law to declare the state DEP "may

${ }^{46} \mathrm{Id}$.

${ }^{47}$ Ho et al., supra note 19 , at 13 .

${ }^{48}$ Id. at $9-10$.

${ }^{49} I d$. at 9.

50 See id. at 52.

${ }^{51}$ Robert J. Burnett, Abandoned Oil and Gas Wells - More Than Just a Rusty Eyesore, Houston HARBAUGH P.C. 4 https://www.hh-law.com/Articles/Oil-and-GasArticles/Abandoned-Oil-and-Gas-Wells-More-Than-Just-a-Rusty-Eyesore.shtml [https://perma.cc/F6N3-FXTD] (last viewed Oct. 10, 2019). 
order the landowner or occupier to correct the condition." 52 Thus, a landowner could be held financially responsible for previously abandoned wells on their property. ${ }^{53}$ This cost is in addition to the possible property and environmental damage an abandoned well can cause, which will generally be imputed upon the property owner if the landowner does not take adequate steps for protection when the well is discovered. ${ }^{54}$

Abandoned wells can also damage the financial interests of producing neighbor wells and lead to blowouts. ${ }^{55}$

The high density of aging and improperly plugged wells is a major risk factor for the current and future development of . . . oil and gas fields. When fields with old wells are reworked using new technology ... the injection of additional fluid and gas increases pressure in a reservoir. Poorly plugged or aging wells often lack the integrity to avoid a blowout. ${ }^{56}$

A blowout results in crude oil being "released uncontrollably," leaving a costly cleanup effort and sometimes causing explosions of rigs and production equipment.57 If the pressure of a neighboring well is lost as a result, this could cause a significant production cost, perhaps in the form of lost profits for the driller. ${ }^{58}$

52 E.g., Adams Sanitation Co. v. Pennsylvania Dep't of Envtl. Prot., 683 A.2d 981, 984 (Pa. 1996), aff'g Philadelphia Chewing Gum Corp. v. Dep't of Envtl. Prot., 387 A.2d 142 (Pa. 1978) (holding an owner liable for water pollution emitted from land where the landowner "knew or should have known of the existence of the condition on the land").

${ }_{53}$ Burnett, supra note 50, at 4-5.

${ }^{54} I d$. at 5 .

55 See Atkinson v. Va. Oil \& Gas Co., 79 S.E. 647, 648, 709 (1913) (claiming a well drilled 100 feet from a producing well caused the product to escape); see also Palmer v. Collins, 284 S.W. 95, 98 (1926) (discussing lawsuit where plaintiff recovered damages for an oil company that failed to plug non-producing wells, leading to water in the producing well's supply).

${ }^{56}$ Kyle Ferrar, Literally Millions of Failing, Abandoned Wells, FRACTRACKER ALLIANCE (Mar. 29, 2019) https://www.fractracker.org/2019/03/failing-abandoned-wells/ [https://perma.cc/6HBN-8U45].

57 What is an Oil Blowout? And Why Does it Happen?, Petro InDustry News

(Aug. 24, 2014), https://www.petro-online.com/news/fuel-for-thought/13/breakingnews/what-is-an-oil-well-blowout-and-why-does-it-happen/31402 [https://perma.cc/C99CYT3U].

${ }^{58} I d$. 
This Note will later address the financial burden of plugging abandoned wells on states and taxpayers in-depth, but it is worth mentioning that plugging an abandoned well in the Basin can cost well over $\$ 20,000 .{ }^{59}$ Pennsylvania's DEP estimates the total cost to close all "highest-risk" abandoned wells in the state could add up to $\$ 5.7$ million. ${ }^{60}$ The Ohio Department of Natural Resources, for example, spent $\$ 6$ million in 2018 plugging eighty-three wells, ${ }^{61}$ with an average cost of over $\$ 82,500$ per well. ${ }^{62}$ Kentucky and West Virginia hold $\$ 950,000$ and $\$ 385,000$ in orphan well funds, respectively. ${ }^{63}$ However, these funds have only plugged a total of forty wells in these two states since $2012 .{ }^{64}$

\section{Environmental Risks}

Unplugged wells create environmental risks, and if left unaddressed, can be as severe as any other environmental issue facing the U.S. today. Significant levels of methane are leaked by over forty percent of unplugged wells, compared to less than one percent of wells properly plugged.65 Methane emissions are responsible for slightly over ten percent of U.S. greenhouse gas emissions and, when leaked into the atmosphere, easily traps

59 Reid Frazier, State Reaches \$7M Agreement Over 1,400 Abandoned Oil and Gas Wells, ALLEGHENY FroNT (Mar. 12, 2019) https://www.alleghenyfront.org/statereaches-7m-agreement-over-1400-abandoned-oil-and-gas-wells/ [https://perma.cc/WE7HUJED].

${ }^{60}$ Laura Legere, New Estimates of Abandoned Pa. Oil and Gas Wells Less Dire, Still Daunting, PosT-GAZETTE (Nov. 28, 2017, 7:00 AM)

https://www.postgazette.com/business/powersource/2017/11/28/New-estimates-abandonedwells-less-dire-still-daunting-Pennsylvania-Engelder/stories/201711280008 [https://perma.cc/R7HT3VVW].

${ }^{61}$ Amy Beth Graves, New Law Speeds Up Plugging of Abandoned Oil, Gas

Wells, OHIO FARM BUREAU (July 23, 2019), https://ofbf.org/2019/07/23/new-law-speedsplugging-abandoned-oil-gas-wells/ [https://perma.cc/LMT6-E5EN].

62 Sophie Quinton, Why 'Orphan' Oil and Gas Wells Are a Growing Problem for States, PEW (July 9, 2018),

https://www.pewtrusts.org/en/researchandanalysis/blogs/stateline/2018/07/09/why-orphanoil-and-gas-wells-are-a-growing-problem-for-states.

${ }^{63}$ Brittany Patterson, Orphan Wells: States Wrestle With Soaring Costs For Oil \& Gas Industry Mess, OHIO VALLEY RESOURCE (Sep. 7, 2018),

https://ohiovalleyresource.org/2018/09/07/orphan-wells-states-wrestle-with-soaring-costsfor-oilgasindustrymess/?_ga=2.176546273.596842650.15706612941934504606.1569246348 [https://perma.cc/BTR4-GYA2].

${ }_{64} \mathrm{Id}$.

${ }^{65}$ Allison \& Mandler, supra note 6. 
heat at a rate far beyond carbon dioxide. ${ }^{6}$ Methane is both colorless and odorless, and can build-up without notice. ${ }^{67}$ In the past several years, methane build-up in abandoned wells led to a series of explosions in western Pennsylvania homes. ${ }^{68}$ Similarly, in 2007, methane leaks from abandoned wells led to an explosion in Colorado and, in 2014, required a school evacuation in Ohio. ${ }^{69}$ A 2016 study found that abandoned wells in the Keystone State are leaking an estimated 50,000 metric tons of methane per year. ${ }^{70}$ A separate 2016 study revealed the highest rate of well methane leakage in the country had occurred in abandoned wells in "Appalachian Ohio."71

Additionally, unattended wells can contaminate groundwater, potentially causing detrimental effects on the surface environment and the surrounding ecosystem. ${ }^{72}$ Abandoned well sites "may still have old equipment, contaminated soil from small spills, and other waste at the surface."73 Wells in the Basin may leak into tributaries of the Ohio River, and offshore wells may release toxins into the open water. ${ }^{74}$ Spillage from wells can leave "oil, natural gas, and brine" in the surface soil, which in turn may inhibit any agricultural use of the surrounding land. ${ }^{75}$

66 Overview of Greenhouse Gases, U.S. EnvTL. Prot. AGENCY,

https://www.epa.gov/ghgemissions/overview-greenhouse-gases\#methane [https://perma.cc/9R6X-AKA5]; Methane: The Other Important Greenhouse Gas,

ENVTL. DEFENSE FUND, https://www.edf.org/climate/methane-other-important-

greenhouse-gas [https://perma.cc/9CEU-7EDE] (last viewed Oct. 27, 2019).

67 Weber, supra note 16.

68 Abandoned Oil Wells Hidden Under Thousands of Local Properties, WPXI

News (Nov. 20, 2018), https://www.wpxi.com/news/top-stories/abandoned-oil-wells-hiddenunder-thousands-of-local-properties/875732284/ [https://perma.cc/DRT5-2JXT].

69 Sophie Quinton, Why 'Orphan' Oil and Gas Wells Are a Growing Problem for States, PEW CHARITABLE TRUSTS (Jul. 9, 2018) https://www.pewtrusts.org/en/researchand-analysis/blogs/stateline/2018/07/09/why-orphan-oil-and-gas-wells-are-a-growingproblem-for-states [https://perma.cc/4JYA-RF9U].

${ }^{70}$ Patterson, supra note 63.

71 Amy Townsend-Small, Thomas Ferrara, DAvid Lyon, ANASTASIa Fries \& BRIAN LAMB, EMISSIONS OF COALBED AND NATURAL GAS METHANE FROM ABANDONED OIL AND GAS WELLS IN THE UNITED STATES (2016).

${ }^{72}$ Allison \& Mandler, supra note 6.

${ }^{73} \mathrm{Id}$.

${ }^{74} \mathrm{Id}$.

75 Shane Hoover, Special Report: Ohio Invests More Money Into Well Plugging, Revamps Program, Repository (July 13, 2015), https://www.cantonrep.com/article/20150713/SPECIAL-REPORTS/150719946 [https://perma.cc/B5B5-7H7Q]. 


\section{Health and Public Safety Risks}

Beyond the adverse effects these environmental risks can have on communities, abandoned wells can pose health and public safety risks. Since many wells in the Basin have not yet been located, they may be sitting below properties, waiting to collapse unbeknownst to property owners. ${ }^{76}$ In Pennsylvania, the locations of only two to four percent of the state's abandoned wells are known, leaving approximately 200,0000 unaccountedfor. ${ }^{77}$ Additionally, since many unsealed abandoned wells are left without proper precautions, children and animals can easily fall into the wells, resulting in serious injury or death. ${ }^{78}$

Groundwater contamination also poses serious health risks for local residents. In Ohio alone, abandoned oil wells contributed to forty-one known instances of groundwater contamination between 1983 and 2007.79 Drinking water in certain areas of Pennsylvania and Texas has been so severely contaminated by methane that residents in recent years could set fire to their tap water. ${ }^{80}$ A 2011 study found, in a fifteen-year period, thirty instances of groundwater pollution from abandoned drilling sites in Texas. ${ }^{81}$ However, these instances merely represent a few of the immediately noticeable effects that leaking orphan wells have on local communities.

\section{Modernizing Regulations}

Each state is left to regulate the industry within its own borders, resulting in a non-uniform system with greatly varying regulations across the country. ${ }^{82}$ Such a system means producers

\footnotetext{
76 Abandoned Wells, IL. DeP’T Pub. Health Div. EnVTl. Health (July 2010), https://www.dph.illinois.gov/topics-services/environmental-health-protection/privatewater/abandoned-wells [https://perma.cc/FW9R-3L5Y].

77 Burnett, supra note 51.

78 DEP'T PUB. HEALTH, supra note 76.

${ }^{79}$ Hoover, supra note 75.

${ }^{80}$ Zoë Schlanger, Fracking Wells Tainting Drinking Water in Pennsylvania and Texas, Study Finds, NewsweEK (Sep. 15, 2014), https://www.newsweek.com/frackingwells-tainting-drinking-water-texas-and-pennsylvania-study-finds-270735 [https://perma.cc/72PB-V5KS].

${ }^{81}$ Malewitz, supra note 18.

82 See Patterson, supra note 63.
} 
who are held accountable in one state may not be in a neighboring state. ${ }^{83}$ Even the definition of what qualifies as an abandoned or orphaned well is not uniform across the Basin. ${ }^{84}$ Thus, an operator opening wells in neighboring states is subject to two separate definitions and held accountable to different extents, both financially and legally. ${ }^{85}$

Since the oldest producing wells in the region date back to 1859, many operated for nearly a century with few or no regulations. ${ }^{86}$ Pennsylvania did not require oil and gas operators to register wells until 1985.87 The lapse of ninety-six years between the beginning of production and the first instance of state-mandated well registration is, to some extent, responsible for the proliferation of abandoned wells in the Keystone State. ${ }^{88}$

Ohio was making vital industry discoveries, but its lack of regulations persisted. In 1884, the discovery of the Lima oil field in northwestern Ohio made the state the largest oil producer in the world at the time. ${ }^{89}$ However, well construction, emissions, and performance standards were not uniformly regulated in Ohio until the 1970s and 1980s. ${ }^{90}$ Permits to drill wells in coal areas were not required until 1910, when there were at least 23,000 wells drilled in the state, and permits for all wells were not required until 1943. ${ }^{91}$ The discovery of the lucrative Utica Shale in 2012 resulted in a new oil boom for Ohio nearly overnight, and the state completely overhauled industry regulations. ${ }^{92}$ The surge brought forty-three million dollars in taxes to six Ohio counties as natural gas production in the state jumped from seventy-eight million to almost 1.5 billion cubic feet in six years. ${ }^{93}$ However, the

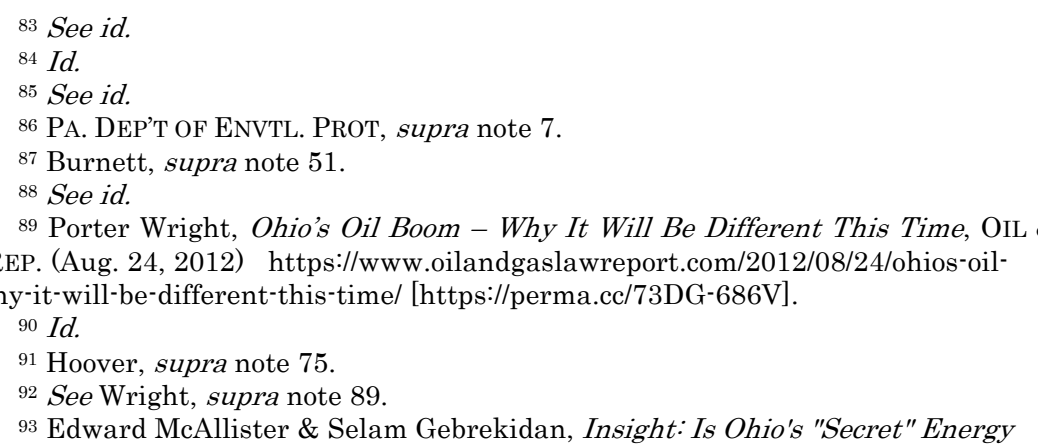
Boom Going Bust?, REUTERS (Oct. 22, 2012, 1:05 AM), https://www.reuters.com/article/usohio-shale/insight-is-ohios-secret-energy-boom-going-bust-idUSBRE89L04H20121022 [https://perma.cc/RJ82-WQ9V]. 
rapid growth likely overwhelmed state regulators. ${ }^{94}$ Due to the lack of modern regulations in Ohio, the boom resulted in instances where oil and gas wells were "as close as 100 feet from a house" even though neighboring Pennsylvania requires wells to be at least 500 feet from a residence..$^{95}$

For decades, there was a lack of registration requirements in Basin states, making it difficult to know exactly how many wells were drilled before the implementation of statewide regulations. Thousands of wells were drilled in the gas-rich Marcellus Shale Formation, the majority of which sits below the Basin, running from Lake Erie to Kentucky. ${ }^{96}$ An estimated 3.7 million wells have been drilled since Drake's well in Pennsylvania in $1859 .{ }^{97}$ Many of these wells are still unaccounted-for and were likely drilled before modern regulations, thus sitting idle decades later..$^{98}$

Regulations regarding the proper process for plugging wells have changed significantly over the years. In addition to unplugged wells, wells plugged improperly before current regulations also cause concern. ${ }^{99}$ An EPA study in the 1980 s estimated as many as 200,000 wells nationally were improperly plugged prior to modern plugging standards. ${ }^{100}$ Any well drilled before 1950 is "particularly likely to have been improperly abandoned and poorly documented."101 Such wells must be replugged in accordance with modern regulations, adding to the staggering costs of plugging those not plugged in the first place. ${ }^{102}$

As of 2017, there were 39,693 unique oil and gas operators registered in the U.S., excluding Texas. ${ }^{103}$ Data currently is

\footnotetext{
${ }_{94} I d$.

95 Julie Grant, Ohio Residents Who Complain About Oil and Gas Feel 'Abandoned' by State, WOSU PUB. MEDIA (Aug. 20, 2019), https://radio.wosu.org/post/ohioresidents-who-complain-about-oil-and-gas-feel-abandoned-state\#stream/0 [https://perma.cc/EBQ7-XGYY].

96 Tim Meko \& Laris Karkilis, The United States of Oil and Gas, WA. PosT (Feb. 14, 2017), https://www.washingtonpost.com/graphics/national/united-states-of-oil/ [https://perma.cc/QYP3-76VP].

${ }_{97}$ Allison \& Mandler, supra note 6.

${ }_{98} I d$.

${ }^{99} I d$.

${ }_{100} I d$.

${ }_{101} I d$.

${ }_{102} I d$.

${ }^{103}$ Kelso, supra note 32.
} 
compiled on a state-by-state basis, without national standards for data transparency. ${ }^{104}$ The lack of uniformity is troublesome when attempting to coordinate efforts amongst states or track repeat offenders across multiple jurisdictions. ${ }^{105}$ Without a uniform system of registration, a state may, without knowledge, grant drilling rights to an operator who has been a repeat offender in a neighboring state.

As production continues to fluctuate, establishing a relatively uniform and effective method of regulation is essential. Kentucky is home to 34,519 oil and gas facilities, located within a half-mile of nearly 404,000 residents. ${ }^{106}$ Over twenty-eight percent of Ohio's population resides within a half-mile of an oil or gas well, and approximately twenty-six percent of West Virginia residents and twelve percent of Pennsylvania residents live within a half-mile of a well site. ${ }^{107}$ Continued failure to adequately regulate drilling of new wells and the plugging of current orphaned wells puts the health of over 6.3 million residents in the Basin at risk, while indirectly affecting over a million more. ${ }^{108}$

\section{THE MODERN INDUSTRY AND IMPLICATIONS OF REGULATORY CHANGE}

There are a multitude of causes for well abandonment in the Basin, and while not all are readily recognizable, many are ascertainable. ${ }^{109}$ Arguably the largest cause of abandonment is directly attributable to the inadequacies of the bond system across the Basin. ${ }^{110}$ Such inadequacies will be addressed in this Note.

$104 \mathrm{Id}$.

105 See id.

106 Oil \& Gas Threat Map, FraCtRACKer Alliance (2020), http://oilandgasthreatmap.com/threat-map/ (classifies a "threat radius" as a half-mile radius around an oil or gas well).

${ }_{107} \mathrm{Id}$.

$108 I d$. (identifying more than 6.3 million residents as within the "threat radius" of an oil or gas well within previously identified Basin states); See, e.g., OHIO RIVER BASIN CONSORTIUM FOR RES. \& EDUC., supra note 3.

109 See Ho et al., supra note 19, at 47.

110 See id. 


\section{A. Increase in Abandoned Wells and the Causes}

\section{Causes for Abandonment}

The bankruptcy of a parent operator is the most common cause of well abandonment.111 Frequently, when wells are no longer economically feasible due to limited production prospects or periods of economic downturn, owner-operators abandon them. ${ }^{112}$ The oil and gas industry is one of inherent volatility, and several different factors can affect profits, such as fluctuating oil prices, concerns of oversupply, world political tensions, and economic turmoil. ${ }^{113}$

An owner-operator may not only abandon a well when it goes dry, but also when it is no longer economically feasible to operate a producing well. ${ }^{114}$ Recently, in Texas, oil prices fell below half the price they had been during a boom, thus driving producers to abandon the wells in hopes of cutting economic losses. ${ }^{115}$ For example, EP Energy filed for bankruptcy after eclipsing five billion dollars in debt. ${ }^{116}$ The producer, which was one of the largest in Texas, would have needed prices of approximately seventy dollars per barrel to be profitable-a price not reached since 2014. ${ }^{117}$ Even after bankruptcy, EP Energy maintains plans to continue operating, without setting aside any funds for the cleanup of failed wells. ${ }^{118}$ This scenario is familiar across the country, and is not foreign to Basin states.

The industry's inherent predisposition to continual reassignment of ownership is another cause of abandonment. ${ }^{119}$

\footnotetext{
${ }^{111}$ Allison \& Mandler, supra note 6.

112 Id.

${ }^{113}$ Duane Dickson, Anshu Mittal \& Andrew Slaughter, Oil's Well?: Divergence and Imbalance in the Oil and Gas Ecosystem, DELOITTE INSIGHTS (Apr. 23, 2019)

https://www2.deloitte.com/us/en/insights/industry/oil-and-gas/decoding-oil-gasdownturn/introduction.html.

${ }^{114}$ Malewitz, supra note 18.

115 Id. ("West Texas crude oil has inched above $\$ 50$ per barrel . . 'Wells were drilled at $\$ 110$ oil you would have never completed otherwise.").

116 Justin Mikulka, As Fracking Companies Face Bankruptcy, U.S. Regulators Enable Firms to Duck Cleanup Costs, EcoWATcH (Dec. 24, 2019), https://www.ecowatch.com/fracking-cleanup-costs-2641678836.html.

${ }_{117} I d$.

$118 I d$.

119 See Howell v. Appalachian Energy Inc., 519 S.E.2d 423, 423 (W. Va. 1999) (private landowner assigned mineral rights to company, who then reassigned to a third
} 
When mineral rights are constantly reassigned from one producer to another, the assignment becomes so far removed from the property owner that it falls on the courts to determine the actual owner of the mineral rights. ${ }^{120}$ Such a determination is costly to states and inhibits state accountability efforts.

Finally, a lack of reporting requirements, even under the modern regulatory system, is a contributing cause to well abandonment. Not all states require reporting of inactive or idle wells. ${ }^{121}$ There are six states nationally with no reporting requirements, three of which are within the Basin. ${ }^{122}$ Additionally, West Virginia only requires reporting by regulators-not operators. ${ }^{123}$ Kentucky, New York, and Pennsylvania require the opposite. ${ }^{124}$ California and Wyoming are the only states in the country that require reporting of inactive wells by both regulators and operators. ${ }^{125}$ Reforming state reporting requirements may be a necessary precaution moving forward, as twelve percent of all inactive wells nationally have not been decommissioned. ${ }^{126}$ Differing state reporting requirements have led to extreme variance in individual abandonment rates ranging from one to fifty-six percent across thirteen oil and gas producing states. ${ }^{127}$

\section{Inadequacies of the Bond System}

Although well abandonment is attributable to a multitude of causes, the current recrudescence of plugging orphaned wells with state tax funds may be primarily attributed to the fundamental inadequacies of the current bond system. ${ }^{128}$ The functional shortcomings of the modern bond system have made it more cost-effective for companies to simply abandon wells rather than properly plug them when wells are no longer lucrative. ${ }^{129}$

\footnotetext{
party prior to bankruptcy. Bankrupt party did not pay royalties for eight years but contested contention that the production site had been effectively abandoned). 120 See id.

${ }^{121}$ Ho et al., supra note 19, at 43.

${ }^{122} \mathrm{Id}$. at 44 . (noting the lack of reporting requirements in Illinois, Indiana, and Ohio).

${ }^{123} I d$.

${ }^{124} I d$.

$125 \mathrm{Id}$.

${ }^{126}$ Id. at 46 .

${ }^{127}$ Ho et al., supra note 19, at 46.

128 See generally Quinton, supra note 69.

${ }^{129} \mathrm{Id}$.
} 
Pennsylvania, for example, has a list of over eight thousand orphaned wells needing service, but only has the bond funds to plug six wells. ${ }^{130}$

When an operator drills a new well, states require financial assurance as security for decommissioning the well, in case the producer does not have the funds to do so in the future. ${ }^{131}$ Generally, this is in the form of a surety bond, but there are many other options, and states typically allow the operator to choose their preferred method. ${ }^{132}$ Several states allow cash payment, which is most secure because it ensures the money to the state upfront. ${ }^{133}$ Aside from cash, surety bonds are the most financially sound because they create a contractual obligation for the third party to pay if the principal fails to do so. ${ }^{134}$ Letters of credit and escrow accounts are also substantially safe forms of assurance. ${ }^{135}$ However, there are less secure options available, including annual payments, liens, and financial statements. ${ }^{136}$ All of these options create a difficult recovery process in the event of operator default. ${ }^{137}$

The primary issue of the bond system is the inadequacy of bond amounts in serving its intended purpose. Many states offer a type of "blanket bond" to operators, allowing a flat cost for all wells drilled in the state rather than a fee per well.138 The blanket bond is nearly always inadequate to cover plugging costs, and it ultimately allows operators to drill additional wells costfree. ${ }^{139}$ For example, Pennsylvania first differentiates bond amounts by well depth. ${ }^{140}$ Wells with a total wellbore length of less than six thousand feet are assessed a bond amount significantly smaller than those exceeding six thousand feet. ${ }^{141}$ After the distinction, the state requires one of four varying levels

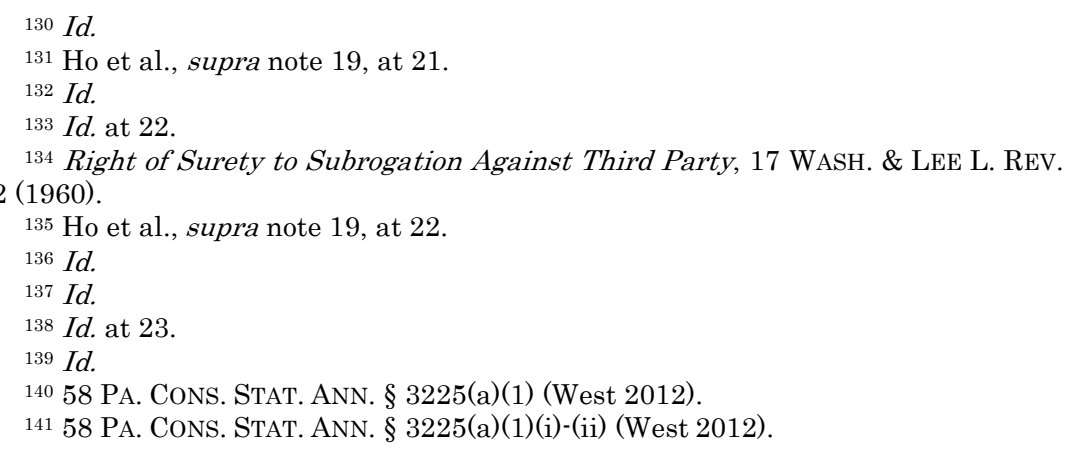


of assurance based on the number of wells owned by the operator within the state. ${ }^{142}$ Although the average cost to plug an abandoned well is $\$ 20,100$, the state requires a maximum $\$ 10,000$ bond per well if over six thousand feet, and a $\$ 4,000$ maximum bond per well less than six thousand feet in depth. ${ }^{143}$ In practice, however, operators pay significantly less per well. ${ }^{144}$

Pennsylvania operators with up to fifty wells less than six thousand feet in depth are assessed bonds of $\$ 4,000$ per well while the total assessment must not exceed $\$ 35,000 .{ }^{145}$ Thus, an operator is financially responsible for less than nine wells and may drill another forty-one wells with virtually no substantive financial responsibility beyond the $\$ 35,000$ cap. ${ }^{146}$ The same deficiency is present at all distinctive levels, and the Pennsylvania system is common to a certain extent across the country. ${ }^{147}$ While the cost to decommission a well varies considerably based on regional and physical characteristics, "average and median decommissioning costs exceed average bond amounts" in nearly every state. ${ }^{148}$

Additionally, some states set bond amounts based on specific well characteristics, such as depth per foot, type, and location. ${ }^{149}$ Many states grant discretionary standards for charging a higher bond dependent on an operator's regulation compliance history and the total number of wells, including inactive wells. ${ }^{150}$ However, no state in the Basin sets bond amounts based on all three of these factors. ${ }^{151}$ Notably, New York sets amounts based solely on well depth, and Ohio sets amounts based only on the number of wells owned by the operator. ${ }^{152}$

${ }_{142} I d$. (stating that for wells less than 6,000 feet in depth, assurance caps are set individually against employers up to fifty wells, fifty-one to 150 wells, 151 to 250 wells, and more than 250 wells. For wells in excess of 6,000 feet, caps are set at up to twenty-five wells, twenty-six to fifty wells, fifty-one to 150 wells, and more than 150 wells).

143 Id.; Malewitz, supra note 18.

14458 PA. CONS. STAT. ANN. § 3225 (West 2012).

14558 PA. Cons. STAT. ANN. § 3225(a)(1)(i)(A) (West 2012).

146 See id. (an operator may own up to fifty wells and is responsible for a $\$ 700$ average bond per well).

147 See, e.g., id.

148 Ho et al., supra note 19 , at 46.

${ }^{149} I d$. at 23 .

${ }^{150} I d$.

${ }^{151} I d$. (noting Arkansas, California, and Colorado set bond amounts based on all three factors).

$$
{ }^{152} I d \text {. }
$$


Kentucky has the lowest minimum individual bonding requirement in the nation, set at $\$ 500$, while Alaska has the highest, charging a $\$ 100,000$ minimum individual bond per well. ${ }^{153}$

Ultimately, the most straightforward step for state legislators to remedy the bond problem involves increasing minimum bondage amounts to an adequate level to cover decommissioning costs. However, factors must be balanced to ensure bonding requirements are not so high as to inhibit production incentives. With limited exceptions, a visual analysis of state-by-state bonding requirements continuously shows the Basin lacking in this area. ${ }^{154}$

B. Modern State of the Industry Under the Trump Administration

\section{Current Oil Boom}

American oil production has surged in recent years due to a wide variety of factors, including regulation cuts, political instability in the Middle East, and newly discovered reserves. ${ }^{155}$ The U.S. oil industry has increased production by more than a million barrels a day every year since $2011 .{ }^{156}$ In turn, U.S. oil imports are at their lowest level in three decades, having fallen seventy-five percent in the last ten years. ${ }^{157}$ Texas alone produces nearly five million barrels per day, more than any country in the Middle East other than Saudi Arabia. ${ }^{158}$ As of 2019, the U.S. produces more than 12.1 million barrels of crude oil per day, making it the largest producer in the world. ${ }^{159}$

In the Basin, Ohio has seen unprecedented growth since 2010. ${ }^{160}$ The success in Ohio came as a result of 1,500 new drilled

\footnotetext{
${ }_{153} I d$. at 25 .

${ }_{154}$ See Ho et al., supra note 19 (Map 2).

155 Robert L. Kleinberg, Is the U.S. Oil Industry Dominant? On the Verge of Oblivion? Neither, N.Y. TIMES (Oct. 7, 2019),

https://www.nytimes.com/2019/10/07/business/United-States-tight-oil-market.html [https://perma.cc/4BE6-BK3A].

$156 I d$.

157 Egan, supra note 25.

158 Id.

${ }_{159} I d$.

${ }^{160}$ Hoover, supra note 75.
} 
wells and a sixty-two percent growth in oil production. ${ }^{161}$ Additionally, Pennsylvania and West Virginia have seen substantial growth in crude oil production this decade. ${ }^{162}$ Ohio, Pennsylvania, and West Virginia were responsible for a total of eighty-five percent of the increase in U.S. natural gas production between 2012 and 2015. ${ }^{163}$ The remainder of the Basin has remained stagnant in production despite the current oil boom. ${ }^{164}$

While production has boomed, oil prices are highly volatile and do not directly correlate to production. ${ }^{165}$ Currently, U.S. oil prices are significantly lower than in 2014 when the price per barrel surpassed $\$ 110 .{ }^{166}$ While U.S. oil production is at an alltime high, crude oil prices are highly volatile and the political instability of the Middle East presents an ongoing risk to the industry. ${ }^{167}$ States in the Basin must take action now to ensure that a sudden downturn in the industry would not cause mass abandonment of wells that were drilled during this time of industry growth.

\section{Regulation Cuts Under the Trump Administration}

The Trump Administration has made regulation cuts across the board, likely impacting the environmental sector the most. ${ }^{168}$ According to the Brookings Institution, the Trump Administration has repealed fourteen acts of environmental regulation and altered dozens more. ${ }^{169}$ These cuts may have a

${ }^{161} I d$.

162 U.S. ENERGY INFO. ADMIN., supra note 29 (noting Ohio production grew from 14 thousand to 64 thousand barrels per day; Pennsylvania from 12 to 18 thousand barrels per day; West Virginia from 7 to 32 thousand barrels per day over a six-year period).

163 AGREement To EnHance Regional CoOperation AND Job Growth Through the Continuing Development of Shale Gas in the Appalachian Basin (Oct. 13, 2015), https://www.tristateshalesummit.com/ [https://perma.cc/4MTA-CWCB].

164 Id.

165 Short-Term Energy Outlook, U.S. EnERgy INFO. AdMIN.,

https://www.eia.gov/outlooks/steo/report/prices.php [https://perma.cc/YVZ68-27F5] (last viewed Jan. 12, 2019).

${ }^{166} I d$.

167 Kleinberg, supra note 155.

168 Tracking Deregulation in the Trump Era, BRoOKINGS INST. (Jan. 8, 2020), https://www.brookings.edu/interactives/tracking-deregulation-in-the-trump-era/ [https://perma.cc/4VKE-MJD2].

${ }^{169} I d$. 
positive effect on industry output but exacerbate the negative effects of the industry, particularly those addressed in this Note.

EPA administrator Scott Pruitt repealed an Obama-era regulation requiring financial assurance from hard rock mining operators to ensure there would be financial means to support the cleanup of pollution of streams and groundwater. ${ }^{170}$ The repeal has led to a situation similar to abandoned oil and gas well cleanup. ${ }^{171}$ In repealing the regulation, Pruitt touted these means of financial assurance as "unnecessary" and claimed they "impose an undue burden on this important sector of the American economy." 172 However, cutting these types of financial assurance requirements, whether in mining or the oil and gas industry, shifts the cost of future cleanup to taxpayers. Despite the negative implications for worker safety and the environment, a 2018 rollback of offshore drilling regulations may "save the industry more than $\$ 1.3$ billion in compliance costs over the next decade." 173 The repealed rules were safety measures implemented following the Deepwater Horizon rig explosion in 2010, which resulted in eleven deaths and the largest marine oil spill in U.S. history. ${ }^{174}$

Most notably, the Administration proposed updates to permit regulations in September 2018, making it substantially easier to obtain a lease to drill in national forests. ${ }^{175}$ Over 4.5 million acres of national forest exist in the Basin, including two million acres alone comprising of the George Washington and Jefferson National Forests, spanning from Kentucky to Virginia. ${ }^{176}$ Granting permits to increase drilling in national

\footnotetext{
${ }^{170} \mathrm{Id}$.

${ }^{171} I d$.

${ }^{172} I d$.

${ }^{173}$ Eric Lipton, Trump Rollbacks Target Offshore Rules 'Written With Human Blood', N.Y. Times (Mar. 10, 2018),

https://www.nytimes.com/2018/03/10/business/offshore-drilling-trump-administration.html [https://perma.cc/S333-3W2k].

${ }^{174} \mathrm{Id}$.

175 Christopher Solomon, Trump Wants to Speed Up Drilling in National Forests, OUTSIDE ONLINE (Dec. 11, 2018), https://www.outsideonline.com/2373896/trumpwants-speed-drilling-national-forests [https://perma.cc/9R5Q-WCWW]; see Mark Hand, Outdated Rules Mean Taxpayers, Not Industry, End Up Paying for Abandoned Oil and Gas Wells, THINkPROGREss (Feb. 26, 2018), https://thinkprogress.org/cleaning-up-afteroil-gas-drilling-d1786d488a6f/ [https://perma.cc/2GEY-LFMA].

176 Land Areas of the National Forest System, U.S. ForEST SYS. (Nov. 2015),

https://www.fs.fed.us/land/staff/lar/LAR2015/FY2015\%20LAR\%20Book.pdf
} 
forests has the potential for environmental damage to our nation's most protected lands, and it creates a difficult scenario where there is federal jurisdiction over wells within a state. ${ }^{177}$ The Bureau of Land Management allows a blanket bond of only $\$ 25,000$ to cover all wells within an individual state or $\$ 150,000$ to cover all wells nationally. ${ }^{178}$ These blanket bonds mean corporations may drill an unlimited number of wells in national forests under reduced regulations by posting the cost of plugging less than eight wells. ${ }^{179}$

While there is no evidence revealing well abandonment as proportionally any less or greater among federal lands compared to state-regulated lands, it is apparent that federal bond amounts are exceedingly inadequate to cover reclamation costs. ${ }^{180}$ "Regulatory bond minimums have not been adjusted since the 1950 s and 1960s to account for inflation," and as a result, eightyfour percent of federal bond amounts would not cover reclamation costs for even the lowest-cost wells. ${ }^{181}$ While allowing an expansion of drilling in national forests will contribute to the monetary benefits of the U.S. oil boom, an accompanying reform of federal bond minimums is necessary to prevent widespread abandonment across the 4.5 million acres of national forest in the Basin. ${ }^{182}$

\section{RECOMMENDATIONS AND PREVENTATIVE ROADBLOCKS}

\section{A. Potential Political, Economic, and Technical Roadblocks to Implementation}

In addition to the generalized success of western states, certain measures within the Basin have been successful and may

[https://perma.cc/VS2C-V6DF] (noting National Forests located within the Ohio River Basin include the Allegheny National Forest in Pennsylvania, Daniel Boone Forest in Kentucky, Finger Lakes National Forest in New York, George Washington and Jefferson National Forests in Kentucky, Virginia, and West Virginia, Hoosier National Forest in

Indiana, Shawnee National Forest in Illinois, and Wayne National Forest in Ohio).

177 Solomon, supra note 175.

178 Ho et al., supra note 19 , at 25.

179 Malewitz, supra note 18.

180 See U.S. Gov'T Accountability OfF., GAO-19-615, Oil and Gas: Bureau of Land Management Should Address Risks from Insufficient Bonds to Reclaim Wells 15 (2019).

\footnotetext{
181 Id. at $15-16$.

182 U.S. FOREST SYS., supra note 176.
} 
act as guidance for neighboring states moving forward. ${ }^{183}$ Specifically, Ohio and Indiana have been more successful in addressing abandoned wells than the remainder of the region; however, these successes are minimized when compared to the results in some western states with much higher production. ${ }^{184}$ Alaska, for example, is responsible for more crude oil production than the entire Basin, yet the northern state has just fifteen abandoned wells on the state's waitlist. ${ }^{185}$ The Basin's unique factors contribute to these shortcomings, and they will be addressed herein.

Several plugging procedures within the Basin have produced positive results. In Ohio, severance taxes on oil and natural gas fund the state's plugging program. ${ }^{186}$ The fund was established in 1977 and was substantively inadequate until 2018, when tax allocation to the fund was doubled. ${ }^{187}$ As a result, the state plugged 233 wells over a twenty-two month period using sixteen million dollars from the fund. ${ }^{188}$ Indiana's well investigatory procedures may also serve as an example of success to neighboring states. Indiana has less than 1,000 abandoned wells in the state and continually updates the list as more wells are reported to the Division of Oil and Gas. ${ }^{189}$ The state individually investigates each well on the waitlist based on six factors, conducts a risk assessment, and plugs the highest-risk wells as funds become available. ${ }^{190}$

183 See generally Ho et al., supra note 19.

${ }^{184} \mathrm{Id}$. at 52-53 (noting that while of eight states nationally with abandoned well share in excess of proportional contribution to U.S. oil production, six of the Ohio River Basin states addressed herein (Illinois, Indiana, Kentucky, Ohio, Pennsylvania, and West Virginia) are included)

$185 \mathrm{Id}$.

186 Graves, supra note 61.

${ }^{187} \mathrm{Id}$.

$188 \mathrm{Id}$.

189 IND. DEP'T NAT. RES., supra note 35.

$190 I d$. ("[W]hether the well is currently leaking . . . into the environment; its proximity to . . . buildings or water supply wells; any immediate threats the well poses to the health or safety of the public, or to that of wildlife or livestock; the fluid levels in the well; whether the well is in an area subject to frequent flooding or close to streams or other environmentally sensitive areas; or whether the well currently poses a significant impediment to existing or proposed commercial or residential development, or to mineral extraction, agricultural, or industrial operations."). 


\section{Political Difficulties}

The power held by lobbyists in the oil and gas industry is one of the most substantial threats to implementing change. "Every year, the world's five largest publicly owned oil and gas companies spend approximately $\$ 200$ million on lobbying designed to control, delay or block binding climate-motivated policy." 191 In some Basin states, lobbying and political influences pose difficult roadblocks to substantive change. While Indiana and Ohio have enjoyed success plugging wells through statesponsored efforts, not all states in the region have shared in the progress. ${ }^{192}$

Often lobbyists or other political players contributing donations are connected to the oil and gas sector. Kentucky state law restricts lobbyists from donating to specific candidates but lobbyists are permitted to donate to political parties. ${ }^{193}$ As a result, Kentucky's political parties received $\$ 319,805$ from registered lobbyists in 2018. ${ }^{194}$ The largest donation came in the form of a $\$ 30,000$ check from John McCarthy, who, among other interests, represents Boardwalk Pipeline Partners, a Texas-based natural gas company. ${ }^{195}$

West Virginia saw several measures fail in the 2019 legislative session that would have made a positive impact on well maintenance. ${ }^{196}$ Senate Bill 665 would have allowed a natural gas driller to receive an expedited permit for an additional $\$ 20,000$, funneled directly to state plugging funds, but

191 Niall McCarthy, Oil and Gas Giants Spend Millions Lobbying To Block Climate Change Policies, Forbes (Mar. 25, 2019),

https://www.forbes.com/sites/niallmccarthy/2019/03/25/oil-and-gas-giants-spend-millionslobbying-to-block-climate-change-policies-infographic/\#22bc70947c4f

[https://perma.cc/Z8RW-CNB7].

192 See generally Tom Loftus, Kentucky Lobbyists Donate Big to State Political Parties, AP News (Apr. 6, 2019), https://apnews.com/fb370b981d6a4b9e9a89fbd849d0510a [https://perma.cc/WMK6-AQUG].

${ }^{193} I d$.

${ }^{194} I d$.

195 Id.; BOARDWALK PIPELINES, https://www.bwpipelines.com/aboutus/default.aspx [https://perma.cc/3KR8-RLH8] (last viewed Jan. 26, 2020).

196 Conor Griffith, Most Well Plugging Legislation Failed '19 Session, W.VA. NEws (Mar. 25, 2019), https://www.wvnews.com/news/wvnews/most-well-plugginglegislation-failed-session/article_e7543575-38f6-5e16-97d3-3475b599a456.html [https://perma.cc/Z6FC-3BFV]. 
it ultimately failed. ${ }^{197}$ Further, House Bill 2673 sought to implement a program similar to Ohio, using severance tax funds to plug an estimated sixty wells per year. ${ }^{198}$ Although it passed both the House and Senate nearly unanimously, Governor Jim Justice vetoed the bill, saying the funds for plugging wells should come from a different source. ${ }^{199}$ The Mountain State has become known as a "revolving door" between industry and government regulatory positions, effectively placing industry executives in a position to regulate the industry where they have a realized stake. ${ }^{200}$ Ultimately, in a state where energy jobs make up six percent of all employment (compared to the national average of 2.3 percent), politicians and constituents may take issue with placing financial burdens on an industry that often provides jobs and revenue in otherwise-struggling local communities. ${ }^{201}$

Similarly, Pennsylvania has experienced difficulties passing meaningful and effective legislation. Senate Bill 790, currently on the legislative docket, seeks allocation of $\$ 5$ million per year of state tax dollars to the Pennsylvania DEP for well plugging. ${ }^{202}$ If passed, Senate Bill 790 would allow the state to preempt local ordinances that regulate drilling. ${ }^{203}$ However, the bill does not address other methods of financing cleanup, nor does any current legislation attempt to resolve the current issues Pennsylvania faces with trying to locate an estimated 200,000

197 Id

198 Nicole Jacobs, West Virginia Governor Vetoes Bill to Plug State's Orphan and Abandoned Oil, Natural Gas Wells, ENERGY In DEPTH (Mar. 29, 2019),

https://www.energyindepth.org/west-virginia-governor-vetoes-bill-to-plug-states-orphanedand-abandoned-oil-natural-gas-wells/ [https://perma.cc/9HR4-QPFN] (noting West

Virginia currently has a well plugging program fund of $\$ 385,000$, compared to Ohio's $\$ 1.8$ million).

${ }^{199} I d$. (noting the bill passed in the Senate with a vote of thirty-three to one and passed the House eighty-nine to eleven; over ninety-one percent of votes supported the bill).

200 Robert Bilott, Exposure: Poisoned Water, Corporate Greed, AND ONE LAWYER'S TWENTY-YEAR BATTLE AGAINST DUPONT 84 (2019).

${ }^{201} I d$. at 101 (author references in a lawsuit against DuPont de Nemours, Inc. that local West Virginia residents were "outraged that anyone would sue the corporation that had 'done so much for the community"'); NAT'L ASS'N ST. ENERGY OfFICIALS \& ENERGY FUTURES INITIATIVE, ENERGY EMPLOYMENT BY STATE - 2019340 (2019).

202 See Senate Environmental Committee Meets Sept. 24 to Move Bill to Regulate Conventional Oil \& Gas Wells, Make Road Dumping of Drilling Wastewater Legal, PA. ENV'T. Dig. (Sept. 20, 2019),

http://www.paenvironmentdigest.com/newsletter/default.asp?NewsletterArticleID=47789 [https://perma.cc/8LKZ-8QV8].

${ }^{203}$ S.B. 790, Gen. Assemb., Reg. Sess. (Pa. 2019). 
thousand wells that remain unidentified. ${ }^{204}$ The state recently settled with Diversified Gas \& Oil Corporation to submit a seven million dollar performance bond to plug 1,400 abandoned wells in Pennsylvania, which may serve as an example of how to hold corporations in the region accountable for cleanup. ${ }^{205}$

However, Pennsylvania is home to recent corruption concerns. ${ }^{206}$ In January of 2020, the FBI initiated a corruption investigation into Governor Tom Wolf's Administration and the state's handling of the well permit process. ${ }^{207}$ The investigation came after the state waited over a year to assess a fine and temporarily shut down a Sunoco project based on '"egregious' violations of environmental laws" during the construction of a pipeline to transport natural gas from Ohio and Western Pennsylvania to Delaware. ${ }^{208}$ Further, while spills of the Mariner East 2 pipeline contaminated Pennsylvania surface and groundwater as early as 2017, it was not addressed until 2020. ${ }^{209}$

Similar political issues exist to varying degrees across the Basin and are traceable to several key causes. Regardless, lobbying will continue to exert significant influence due to the importance and lucrativeness of the oil and gas industry. ${ }^{210} \mathrm{In}$ 2019 , the industry garnered nearly $\$ 125$ million in contributions, and over 80 percent of members in the U.S. Congress received contributions from oil and gas lobbyists. ${ }^{211}$ A legislative solution, such as Senate Bill 665 in West Virginia, must adequately address abandonment problems yet continue to provide a favorable result for the oil and gas industry. ${ }^{212}$

Although some states have been more successful in remediating the problem, substantial regulatory steps remain to

204 Burnett, supra note 51.

205 Frazier, supra note 59.

${ }^{206}$ Nina Lakhani, 'We Can't Live Like This': Residents Say a Corrupt Pipeline Project is Making Them Sick, GUARDIAN (Jan. 27, 2020), https://amp.theguardian.com/usnews/2020/jan/27/pennsylvania-residents-mariner-east-pipelines-drinking-watercontamination [https://perma.cc/N3XJ-T56J].

$207 \mathrm{Id}$.

${ }^{208} I d$.

${ }^{209} I d$. (noting a separate fine assessed for a series of independent fluid spills in 2017 was not reported for over 500 days).

210 See Oil \& Gas: Money to Congress, CTR. For Responsive POL., opensecrets.org/industries/summary.php?cycle=2020\&ind=E01

[https://perma.cc/W34C-AJKW] (last visited Jan. 25, 2020).

211 Id.

212 See Griffith, supra note 196. 
achieve results comparable to states outside the Basin. As of 2016, the seven western states with the fewest abandoned wells on state waiting lists collectively had fewer wells than Indiana, which had the fewest number of abandoned wells in the Basin. ${ }^{213}$ Thus, all states in the Basin can look to western states for guidance on reforming regulatory measures.

\section{Economic Cost to States and Technical Roadblocks to Implementation}

Even with adequate legislative and regulatory reform, states still face the economic and technical difficulties associated with implementation. ${ }^{214}$ As previously stated, plugging a well can cost over $\$ 20,000$ depending on the well characteristics involved. ${ }^{215}$ While Ohio serves as a model in the Basin for plugging orphaned wells, such a system comes at an expense. ${ }^{216}$ Over a two-year period, the state spent $\$ 16$ million plugging 233 wells. ${ }^{217}$ Ohio is currently soliciting bids to plug 200 wells in the state, which may amount to a 25 million dollar expenditure. ${ }^{218}$

Wells improperly plugged prior to the implementation of modern standards pose an even higher cost to states to remediate than the standard abandoned well. ${ }^{219}$ There is no shortcoming of such a class of wells in the region considering the Basin's extensive history with the industry. ${ }^{220}$ Not only is the cost to plug these wells generally more than those not plugged in the first place, but improperly plugged wells present unique financial risks to neighboring wells if not adequately addressed. ${ }^{221}$

Technical roadblocks exist as well, especially since the large majority of orphan wells in the region sit on private

${ }^{213}$ Ho et al., supra note 19, at 52-53 (noting Alaska, Colorado, Montana, Nebraska, New Mexico, North Dakota, and Utah have 302 wells on state waitlists, despite being responsible for a 33.3 percent of U.S. crude oil production; Indiana has over 500 wells on the state waitlist, but is responsible for $1.0 \%$ of U.S. oil production).

${ }^{214}$ Malewitz, supra note 18.

$215 \mathrm{Id}$.

${ }^{216}$ See Graves, supra note 61.

217 Id.

218 Shane Hoover, ODNR Seeking Well Pluggers, AKRON BEACON J. (Jan. 2,

2020), https://www.beaconjournal.com/news/20200102/odnr-seeking-well-pluggers [https://perma.cc/UR2Q-9WB7].

${ }^{219}$ Ho et al., supra note 19, at 10.

${ }_{220}$ First American Oil Well, supra note 26; see generally Ferrar, supra note 56.

221 See id. 
lands. ${ }^{222}$ If a private landowner has an orphaned well on their land, the landowner may not be able to have it plugged if it does not pose a sufficient risk to warrant immediate state attention. ${ }^{223}$ Under Ohio's orphan well program, landowners may seek a general contractor to plug a well on owned lands, but still, it requires pre-approval by the state and is only available on a priority basis until funds for the year are depleted. ${ }^{224}$ Additional property law concerns may arise in states where there is not a recognized right of entry to inspect and plug orphaned wells on private property. ${ }^{225}$

\section{B. Recommendations}

\section{Currently Abandoned Well Mitigation Recommendations}

\section{(a) State-Mandated Reporting Requirements}

No state in the Basin requires reporting of well abandonment by both an operator and regulator. ${ }^{226}$ Further, Illinois, Indiana, and Ohio require no reporting at all. ${ }^{227}$ Requiring reporting by both operators and regulators would prevent situations like in Pennsylvania, where the locations of tens of thousands of wells are undetermined. ${ }^{228}$ The first step to mitigating the problem is knowing where to look. As such, requiring reporting by all parties involved is an easy solution. ${ }^{229}$ Similarly, states must take measures to locate abandoned wells actively. In addition to record searches, localities may use technology such as aerial photographic interpretation,

222 Burnett, supra note 51.

223 Id.

${ }^{224}$ Important Things To Know About Orphan Wells, OHIO DeP'T NAT. RES., http://oilandgas.ohiodnr.gov/portals/oilgas/pdf/orphan/Orphan\%20Well\%20Program\%20Br ochure_2014.pdf [http://perma.cc/55CX-8493] (last viewed Jan. 26, 2020).

225 See Ho et al., supra note 19, at 10.

${ }^{226}$ See id.

227 Id. at 44

228 See Burnett, supra note 51.

${ }^{229}$ Ho et al., supra note 19, at 44 (California and Wyoming are the only states in the country which require reporting of abandoned wells by both operators and regulators and California has just 430 abandoned wells on the state wait list. Wyoming abandonment information was not gathered by the study.). 
magnetometers, and ground-penetrating radars. ${ }^{230}$ While such technology varies in cost, it is a necessary step to mitigation of currently abandoned wells. ${ }^{231}$

(b) Implementation of a Uniform Regulatory System Prior to State Plugging Program

While it may seem intuitive, before undertaking any comprehensive overhaul of a plugging program, Basin states must ensure they have a uniform regulatory scheme to address the plugging process. Many states noticeably lack specific regulatory requirements for plugging processes, which indicates they likely "approach each well on a case-by-case basis." 232 The only scenario more detrimental to states than the current situation is one where a state invests millions in a statewide plugging effort only to determine that the wells were improperly plugged and must be corrected later.

\section{Cleanup}

(c) Implementation of a State Severance Tax to Fund Well

In funding well cleanup, states must ensure the industry, rather than taxpayers, pay the cost. The implementation of a severance tax, similar to the tax used in Ohio, is the most effective method of achieving that end. The Ohio severance tax funneled $\$ 16$ million into well cleanup funds over a two-year period. ${ }^{233}$ Even Ohio's successful program assesses less than a five percent tax over the lifetime of a well, whereas North Dakota uses an 11.5 percent tax rate, and Alaska has a comparable rate of 12.5 to 15 percent. ${ }^{234}$ In fact, in 2016 , West Virginia was the

230 See, e.g., Linda Aller, Methods for Determining the Location of Abandoned Wells, INLAND WeTLANDS \& WATERCOURSES AGENCY/EnVTL. PROT. AGENCY (Jan. 1984), https://nepis.epa.gov/Exe/ZyPDF.cgi/9101QWSO.PDF?Dockey=9101QWSO.PDF [https://perma.cc/VD9L-BJHX].

231 Id.

232 Ho et al., supra note 19 , at 35 .

233 Graves, supra note 61.

234 Oil and Gas Severance Tax, OHIo EnvTl. Council (Apr. 18, 2013), https://theoec.org/fact-sheets/oil-gas-severance-tax/; see generally, Wendy Patton, Low Oil and Gas Severance Taxes Costs Ohio Millions, PoL'Y MATTERs OHIo (Apr. 20, 2017), https://www.policymattersohio.org/press-room/2017/04/20/low-oil-and-gas-severance-taxcosts-ohio-millions [https://perma.cc/ZYQ3-2Y5Q]. 
only state east of the Mississippi River (other than Louisiana) where severance tax revenue exceeded one percent of total state and local general revenue. ${ }^{235}$ A sufficient severance tax on extraction would reassign fiscal responsibility for cleanup from taxpayers back to owner-operators.

\section{Addressing and Preventing Future Abandonment}

\section{(a) Abandoning the Blanket Bond System}

The current administration of the blanket bond system represents the most blatant inadequacy of the Basin states. ${ }^{236}$ Blanket bonds in the Basin do not sufficiently cover the actual costs of plugging abandoned wells. ${ }^{237}$ While there are many relevant factors to consider, there is a direct correlation between reduced blanket bond costs and proliferation of well abandonment. ${ }^{238}$ Although the cost to plug a well can exceed $\$ 20,000$, only four Basin states have a minimum blanket bond more than that amount. ${ }^{239}$ In Kentucky and Ohio, corporations may drill a plethora of wells across the state and must front financial assurance for less than the cost to plug one. ${ }^{240} \mathrm{By}$ comparison, Alaska requires a blanket bond of at least $\$ 200,000$ and has only fifteen abandoned wells on the entire state waitlist. ${ }^{241}$ Basin states should begin by reforming the blanket bond system. However, as the cost of plugging wells depends on a variety of factors unique to each state, the best approach would be to abolish the blanket bond system entirely and require bonds to be posted solely on a per-well basis.

\footnotetext{
235 State and Local Finance Initiative, URBAN INST., https://www.urban.org/policy-centers/cross-center-initiatives/state-and-local-financeinitiative/state-and-local-backgrounders/severance-taxes [https://perma.cc/C9LS-5WEB] (last viewed Jan. 27, 2020).

236 See Ho et al., supra note 19, at 23.

237 Id. at 16.

${ }^{238} I d$. at $23-26$.

${ }^{239} I d$. (noting Illinois and Pennsylvania have minimum blanket bond amounts of $\$ 25,000$; Indiana of $\$ 45,000$; West Virginia of $\$ 50,000)$; Malewitz, supra note 18.

${ }^{240}$ Ho et al., supra note 19, at 26.

${ }^{241}$ Id.; see generally Melinda Bolton, BP Ordered to Plug and Abandon $14 \mathrm{Wells}$, Review All in State, KTUU (Jan. 12, 2019), https://www.ktuu.com/content/news/BPordered-to-plug-and-abandon-14-wells-review-all-in-state-504284621.html [https://perma.cc/YTG8-PQ2L].
} 
(b) Reformation of the Individual Bond System and Reexamination of Financial Assurance Offerings

In addition to reform of the blanket bond system, the individual bond system also needs improvement. ${ }^{242}$ Kentucky holds the lowest individual bond rate in the country of $\$ 500$, while several western states require at least $\$ 25,000 .{ }^{243}$ Ohio and West Virginia have the highest minimum individual bond in the Basin, but still fall short of the actual cost of plugging abandoned wells. ${ }^{244}$ Adequate reform of the bond system would require posting financial assurance to cover the tangible cost of decommissioning the well, determined by a variety of factors such as well depth, location, and well type. ${ }^{245}$ Additionally, the states should incorporate a system that considers the number of inactive wells and compliance history of an operator within the state. ${ }^{246}$

While increasing bond amounts, states may simultaneously reform the methods of financial assurance they allow to ensure operators are financially at the will of the state rather than the opposite. After determining a proper bond amount to cover future plugging of the well, the state should offer operators the choice between up-front cash or a surety bond. ${ }^{247}$ Financial statements, liens, and annual fees are inadequate or difficult to enforce, and states should conduct studies into whether these forms of assurance should be eliminated entirely. ${ }^{248}$ Should states choose to retain less-assured forms of financial assurance, they should be limited to owner-operators with a clean compliance history, rather than allowing companies to choose the lowest-risk method of assurance.

\footnotetext{
242 See generally Ho et al., supra note 19, at 26.

243 Id.; see KY. REV. STAT. ANN § 353.590 (West 2013).

${ }^{244}$ Ho et al., supra note 19, at 26. (noting Ohio and West Virginia have a minimum individual bond of $\$ 5,000$ as shown in Map 2).

${ }^{245} \mathrm{Id}$. at 23.

${ }^{246} I d$.

247 Id. at 21

248 Id. at 22 .
} 
(c) Collaborative Efforts to Document Interstate Compliance Records

Collaborative efforts are necessary to ensure records of compliance history extend across state lines. Basin states should enable a database of compliance violations so an operator may not skirt past liabilities in one state and still fund wells in another. Implementing this system may require additional coordinated communications, such as the establishment of a region-specific definition for what qualifies as an abandoned well, as the definition currently varies across state lines. ${ }^{249}$ State collaborative efforts to expand the industry already exist, and there is no reason this same coalition or one modeled after it could not implement the same methods to oversee abandoned wells in the region. ${ }^{250}$

\section{(d) Reformation of Temporary Abandonment and} Accompanying Shut-In Requirements

Additional regulatory reform may prevent future abandonment of wells by reducing the period where operators can temporarily abandon such wells. Such temporary abandonment allows the operator to stop production but does not immediately decommission the well. ${ }^{251}$ This process effectively allows the operator to avoid decommissioning costs despite the well's potentially low future economic potential. ${ }^{252}$ While this type of reform is occurring in the Basin and other western states, there is still room to reduce the duration period associated with temporary abandonment to lessen the odds of environmental

249 Patterson, supra note 63 (defining an abandoned well as a well that lacks an operator or company that can pay to plug them, leaving state regulators responsible for such action).

250 See Paul J. Gough, Why Pennsylvania, West Virginia, and Ohio are Working Together to Build Petrochemical Industry, PitTsBurgh Bus. Times (June 27, 2016), https://www.bizjournals.com/pittsburgh/news/2016/06/27/why-pennsylvania-west-virginiaand-ohio-are.html [https://perma.cc/82DX-GGAU] (describing the establishment of a collaborative effort of three Basin states to form the Tri-State Shale Coalition, with additional plans to "expand further into Kentucky, Michigan, Indiana and Illinois."); TRI-STATE REgIONAL OPERATION AGREEMENT, supra note 163.

251 Ho et al., supra note 19 , at 29.

$252 I d$. 
damage. ${ }^{253}$ Currently, Pennsylvania and West Virginia allow for a well to be temporarily abandoned for up to five years before it is legally considered abandoned..$^{254}$ States across the Basin should seek to reduce this period to one year to limit the environmental damages associated with temporarily abandoned wells and to mitigate the inability to locate a former operator. ${ }^{255}$ Alternatively, states may seek to extend this period for a supplemental fee in addition to a statement of future usefulness. ${ }^{256}$

In further reducing environmental externalities, implementation of shut-in regulations during periods of temporary abandonment could limit emissions and safety hazards while the wells remain idle. ${ }^{257}$ Shut-in requirements mandate that an operator must apply some form of surface-level cap to a temporarily abandoned well to prevent air emissions and groundwater pollution. ${ }^{258}$ While most Basin states enforce such prescriptive shut-in regulations, a majority of western states do not.259 Preventing adverse environmental effects through a surface level cap should be at the forefront of state efforts, so long as such a regulation would be explicit and prescriptive to not inhibit or create additional costs for permanently plugging the well in the event of future abandonment.

\section{CONCLUSION}

The U.S. oil and gas industry traces its roots back to 1859 in Western Pennsylvania, proving to be a lucrative source of revenue for the country ever since. ${ }^{260}$ While production output for the Ohio River Basin region may be insignificant relative to world production, the effects of abandoned wells pose a substantiated

${ }^{253} I d$. at 30 (noting that California allows up to 300 months abandonment, while several other western states allow 60 months according to Map 5).

${ }^{254} \mathrm{Id}$.

$255 I d$. at 18.

${ }^{256} I d$. at 32 (identifying Basin states in Map 7 that already require a showing of future usefulness to some extent before being granted an extension to temporary abandonment).

${ }^{257}$ Ho et al., supra note 19 , at 34.

$258 I d$.

${ }^{259} \mathrm{Id}$. at 34 (identifying Basin states in Map 8 compared to western states that have shut in requirements during temporary abandonment).

${ }^{260}$ First American Oil Well, supra note 26. 
threat to the water and environment in this region. ${ }^{261}$ As of 2006 , there were 28,047 orphaned wells within six Basin states reported on their respective state's waitlist. ${ }^{262}$ Without accounting for the thousands of additional well locations that are unknown, the Basin is responsible for over 47 percent of identified abandoned wells nationally. ${ }^{263}$

If current inadequacies in regulation remain unaddressed, as the economic output of the oil and gas industry within the region continues to grow, so does the risk of potential abandonment of wells drilled during the boom. ${ }^{264}$ Thus, substantive measures are needed now to mitigate the current issue of abandonment in the region and simultaneously reform legislation to prevent rampant abandonment in the future. Without change, the region stands to face continued and pressing environmental, economic, and human health risks from the widespread issue of orphaned oil and gas wells in the Ohio River Basin. ${ }^{265}$ Should Basin states seek to adequately address abandoned oil and gas wells in the region, the first of many vital measures is the abandonment of the blanket bond system.

261 See generally FRACTRACKER ALLIANCE, supra note 106.

262 Ho et al., supra note 19 , at 52 (identifying Indiana, Kentucky, Ohio, Pennsylvania and West Virginia in Appendix A2 in comparison to the total number of orphaned wells on wait lists in 2006 as reported by the Interstate Oil and Gas Compact Commission).

${ }^{263}$ Id. at 52-53 (comparing Indiana, Kentucky, Ohio, Pennsylvania and West Virginia's production of 737.7 million barrels of oil from 1981 to 2014 to U.S. total production of 69.4 billion barrels).

${ }^{264}$ See generally Id. (describing the growing financial and environmental concern for inactive wells).

${ }^{265} I d$. 